\title{
PELATIHAN PEMANFAATAN TEKNOLOGI INFORMASI PADA MASYARAKAT DI KELURAHAN BELAKANG PADANG KOTA BATAM
}

\author{
Sasa Ani Arnomo \\ Universitas Putera Batam (UPB), Batam, Indonesia \\ e-mail: sasaupb@gmail.com \\ Yuli Siyamto \\ Universitas Putera Batam (UPB), Batam, Indonesia \\ e-mail: ysiyamto46@gmail.com
}

\begin{abstract}
The influence of globalization with the support of information technology is a doubleedged sword. On the other hand, we cannot deny the benefits and threats it brings on the other. Thus, these benefits are also called positive effects and threats are called negative effects. The positive influence that can be felt by Information Technology is an increase in speed, accuracy and convenience. It provides efficiency in various fields, especially in terms of time, energy and costs. For example, the manifestation of Information Technology that is easily seen around us is email where sending a letter only takes a short time. Information technology is also utilized in the field of economic activities such as E-banking, E-commerce, e-shopping and many more. Meanwhile, the negative impact that may arise as a result of information technology is pornography, while the economic aspect of globalization is the opening of free markets that allow foreign products to enter easily. The large number of foreign products and the addition of relatively cheaper prices can reduce the attractiveness of domestic products. This is a big challenge for SMEs in business competition. Financial fraud and embezzlement through electronic media are also rife so it is necessary to learn how to do business online. With this background, there is a need for guidance on how to deal with developments in information technology. As many as 93\% of the responses from the community stated that they were very good and useful.
\end{abstract}

Keywords - Information technology, coastal communities, community service

\section{PENDAHULUAN}

Sejak dulu teknologi sudah ada atau manusia sudah menggunakan teknologi. Seseorang menggunakan teknologi karena manusia memiliki akal dan pikiran. Dengan akalnya ia ingin keluar dari masalah, ingin hidup lebih baik, lebih aman dan sebagainya. Perkembangan teknologi terjadi karena seseorang menggunakan akalnya dan pikirannya untuk menyelesaikan setiap masalah yang dihadapinya. Di Negara-negara yang sedang berkembang, tentunya memerlukan begitu banyak hal untuk mendukung perkembangan negara mereka. Negara-negara tersebut saling meningkatkan berbagai kemampuan mereka dalam segala aspek 
kehidupan masyarakat seperti pada aspek pertanian serta industri. Kemudian, selain itu mereka juga mengadakan investasi dalam aspek kesehatan masyarakat begitu pula dalam aspek Pendidikan.

Dan saat ini, segala aspek kehidupan tersebut telah mampu berkembang dengan pesatnya, perkembangan tersebut beriringan pula dengan perkembangan masyarakat dari masyarakat yang tradisional menjadi masyarakat moderen, kemudian secara otomatis perkembangan tersebut menuntut masyarakat menuju kearah globalisasi. Penyebab utama yang paling terasa pada perubahan tersebut adalah pada aspek Teknologi Informasi, contoh paling sederhana tentang hal ini adalah bila pada masyarakat yang masih tradisional dahulu dalam pencapaian informasi dari jarak jauh memerlukan waktu yang begitu lamanya, karena saat itu masih menggunakan cara pengiriman pesan masih sederhana yaitu surat-menyurat, kemudian berkembang menjadi faksimile kemudian telepon dan sekarang pada tingkat yang lebih moderen telah muncul telepon genggam dalam beragam jenis dan fitur-fitur canggih yang mendominasinya. Perkembangan teknologi informasi selain terlihat di kualitas informasi (Arnomo, 2018) juga pada perkembangan toko online (Arnomo, 2018).

Tentu kemajuan teknologi ini menyebabkan perubahan yang begitu besar pada kehidupan umat manusia dengan segala peradaban dan kebudayaannya. Perubahan ini juga memberikan dampak yang begitu besar terhadap transformasi nilai-nilai yang ada di masyarakat. Khususnya masyarakat dengan budaya dan adat ketimuran seperti Indonesia. Saat ini, di Indonesia dapat masyarakat saksikan begitu besar pengaruh kemajuan teknologi terhadap nilai-nilai kebudayaan yang di anut masyarakat, baik masyarakat perkotaan maupun pedesaan (modernisasi). Kemajuan teknologi seperti televisi, telepon dan telepon genggam (HP), bahkan internet bukan hanya melanda masyarakat kota, namun juga telah dapat dinikmati oleh masyarakat di pelosok-pelosok desa. Akibatnya, segala informasi baik yang bernilai positif maupun negatif, dapat dengan mudah di akses oleh masyarakat. Dampak positif misalnya, kemudahan dalam berkomunikasi lewat telepon seluler atau internet, mudahnya mendapatkan informasi dari internet untuk belajar (Ekawati, 2020). Sedangkan hal negatifnya ialah, banyaknya kasus penipuan lewat sms, akun facebook yang dibobol, dan yang lebih parah lagi sandi atau password ATM yang mudah dibobol oleh orang-orang yang tidak bertanggung jawab. Dan di akui atau tidak, perlahan-lahan mulai mengubah pola hidup dan pola pemikiran masyarakat dengan segala image yang menjadi ciri khas mereka. Dari penjelasan tentang Latar Belakang Masalah maka kelompok kami tertarik untuk melakukan pelatihan pemanfaatan teknologi informasi pada masyarakat di Kelurahan Belakang Padang Kecamatan Belakang Padang Kota Batam.

Sasaran dari pengabdian ini adalah semua masyarakat Kelurahan Belakang Padang, khususnya anak muda yang ingin memperoleh pengetahuan tentang teknologi informasi. Tujuan dari diselenggarakannya pengabdian ini adalah menjadikan masyarakat Kelurahan Belakang Padang membuka mata untuk teknologi informasi sehingga dapat mengikuti perkembangan jaman yang pesat dibidang teknologi. Manfaat yang diharapkan setelah mengikuti penyuluhan adalah sebagai berikut: 
1) Mendistribusikan informasi yang relevan untuk pembangunan;

2) Memberdayakan masyarakat yang kurang beruntung (disadvantaged) dan terpinggirkan (marginalized);

3) Mendorong usaha mikro(fostering microentrepreneurship);

4) Meningkatkan layanan informasi kesehatan jarak jauh (telemedicine);

5) Memperbaiki pendidikan melalui e-learning dan pembelajaran-seumur-hidup (life-long learning);

6) Mengembangkan perdagangan melalui ecommerce;

7) Menciptakan ketataprajaan (governance) yang lebih efisien dan transparan melalui egovernance;

8) Mengembangkan kemampuan;

9) Memperkaya kebudayaan;

10) Menunjang pertanian;

11) Menciptakan lapangan kerja (creating employment); dan

12) Mendorong mobilisasi sosial.

\section{METODE}

Sebelum kegiatan Pengabdian Masyarakat dilaksanakan perlu adanya persiapan berikut:

1) Mengadakan komunikasi dan korespondensi dengan pihak Kelurahan Belakang Padang, terkait dengan ijin pelaksanaan pengabdian masyarakat ini.

2) Dengan seijin Lurah Belakang Padang serta dengan berkoordinasi pihak RW/RT Pulau Belakang Padang beberapa hari sebelum pelaksanaan maka masyarakat setempat bersedia menyambut dengan terbuka dan menyediakan tempat serta peralatan yang diperlukan.

3) Mempersipakan materi kegiatan, khususnya materi ekonomi kreatif yang diperlukan agar pelaksanaan dapat mudah dipahami, menarik dan lancar.

4) Setelah persiapan selesai, tim menuju Pulau Belakang Padang menggunakan speedboat dari Pulau Belakang Padang. Untuk selanjutnya acara digelar di Masjid di Pulau Belakang Padang.

Proses kegiatan pengabdian berlangsung dengan cara narasumber menjelaskan materi. Setelah acara pembukaan oleh Ketua LPPM dan Ketua RT untuk memberikan sambutan, dilanjutkan dengan acara pokok yaitu presentasi/penjelasan tentang pendekatan materi yang disudah dipersiapkan terlebih dahulu.

Adapun proses kegiatan penyuluhan berupa:

1) Peserta penyuluhan diberi materi tentang prospek ekonomi kreatif contohcontoh yang kongkrit yang bisa dimengerti oleh peserta.

2) Peserta penyuluhan diberi kesempatan untuk bertanya kepada narasumber dengan leluasa apabila ada materi yang belum bisa di pahami atau ada masalah-masalah yang berhubungan dengan aktivitas ekonomi yang sedang dijalankan.

3) Metode Tanya jawab secara langsung kepada instruktur. 
Adapun evaluasi pelaksanaan kegiatan untuk mengukur hasil pengabdian adalah sebagai berikut:

Tabel 1 Evaluasi Pelaksanaan Kegiatan

\begin{tabular}{|l|l|l|l|}
\hline \multicolumn{2}{|c|}{ Tujuan } & Indikator Ketercapaian & \multicolumn{1}{|c|}{ Tolok Ukur } \\
\hline $\begin{array}{l}\text { Pemahaman } \\
\text { dampak }\end{array}$ & Ketergantungan & $\begin{array}{l}\text { Peserta termotivasi } \\
\text { Teknangani anak yang } \\
\text { ketergantungan }\end{array}$ & $\begin{array}{l}\text { Peserta akan } \\
\text { menerapkan materi }\end{array}$ \\
\cline { 2 - 4 } $\begin{array}{l}\text { Sosial \& } \\
\text { Psikologis }\end{array}$ & $\begin{array}{l}\text { Violence and } \\
\text { Gore }\end{array}$ & $\begin{array}{l}\text { Peserta termotivasi } \\
\text { menyaring informasi }\end{array}$ & $\begin{array}{l}\text { Peserta akan } \\
\text { menerapkan materi }\end{array}$ \\
\cline { 2 - 4 } & Pornografi & $\begin{array}{l}\text { Peserta mengidentifikasi } \\
\text { jenis situs yang mengarah } \\
\text { pornografi }\end{array}$ & $\begin{array}{l}\text { Kemamnpuan } \\
\text { memblok situs } \\
\text { pornografi }\end{array}$ \\
\cline { 2 - 5 } & Antisocial & $\begin{array}{l}\text { Peserta berlatih } \\
\text { bersosialisasi yang baik }\end{array}$ & $\begin{array}{l}\text { Meningkatkan } \\
\text { interaksi dan } \\
\text { mengurangi } \\
\text { ketergantungan } \\
\text { internet }\end{array}$ \\
\hline $\begin{array}{l}\text { Dampak } \\
\text { Teknologi } \\
\text { Informasi Bagi } \\
\text { Pendidikan }\end{array}$ & $\begin{array}{l}\text { Malas belajar dan } \\
\text { mengerjakan } \\
\text { tugas }\end{array}$ & $\begin{array}{l}\text { Peserta dapat memantau } \\
\text { kegiatan belajar anak }\end{array}$ & $\begin{array}{l}\text { Meningkatnya } \\
\text { kualitas dan } \\
\text { kuantitas belajar }\end{array}$ \\
\cline { 2 - 5 } & $\begin{array}{l}\text { Perubahan } \\
\text { kemalasan } \\
\text { menulis(tulisan } \\
\text { tangan) }\end{array}$ & $\begin{array}{l}\text { Peserta membuat } \\
\text { karangan cerita yang } \\
\text { bermanfaat }\end{array}$ & $\begin{array}{l}\text { Menghasilkan karya } \\
\text { tulisan }\end{array}$ \\
\hline $\begin{array}{l}\text { Dampak } \\
\text { Teknologi } \\
\text { Informasi Bagi } \\
\text { Ekonomi }\end{array}$ & Penjualan online & $\begin{array}{l}\text { Memanfaatkan media } \\
\text { sosial }\end{array}$ & $\begin{array}{l}\text { Memulai pemasaran } \\
\text { secara online }\end{array}$ \\
\hline
\end{tabular}

\section{HASIL DAN PEMBAHASAN}

Salah satu daerah yang belum terjangkau teknologi dan internet adalah Kepulauan kecil di Batam, Pulau Belakan Padang. Kami sangat heran bagaimana mungkin masyarakat disini khususnya para remajanya baru mengenal yang namanya facebook. Lebih miris lagi gaung program internet masuk desa seperti hanya program balon kempes saja. Tak ada penyuluhan tentang internet di desa yang mayoritas warganya adalah nelayan ini. Adapun hasil analisis dampak dari perkembangan teknologi informasi terhadap masyarakat adalah sebagai berikut:

1) Dampak Teknologi Informasi Sosial \& Psikologis

a) Ketergantungan

Media komputer memiliki kualitas atraktif yang dapat merespon segala stimulus yang diberikan oleh penggunanya. Terlalu atraktifnya, membuat penggunanya seakan-akan menemukan dunianya sendiri yang membuatnya terasa nyaman dan tidak mau melepaskannya. kita bisa menggunakan komputer sebagai pelepas stress dengan bermain games yang ada. 


\section{Solusi :}

Ketergantungan dapat ditanggulangi atau diminimalisasikan dengan adanya bantuan dari lingkungan dan orang-orang sekitar kita, yang dapat menyadarkan pengguna addict tersebut dengan menawarkan kegiatan lain yang lebih menarik dari pada yang ditawarkan oleh komputer. Serta memberikan motivasi untuk memperbanyak kegiatan di luar rumah (menyibukkan diri) seperti olahraga, traveling, bersosialisasi dengan teman, maka akan lebih sedikit waktu yang dihabiskan di depan komputer.

\section{b) Violence and Gore}

Kekejaman dan kesadisan juga banyak ditampilkan pada komputer. Karena segi isi pada dunia internet tidak terbatas, maka para pemilik situs menggunakan berbagai macam cara agar dapat menjual situs mereka. Salah satunya dengan menampilkan hal-hal yang menunjukan kekejaman dan kesadisan. Studi eksperimental menunjukkan bahwa ada korelasi positif antara bermain permainan komputer dengan tingkat kejahatan di kalangan anak muda, khususnya permainan komputer yang banyak memuat unsur kekerasan dan pembunuhan. Bahkan ada sebuah penelitian yang menunjukkan bahwa games yang di mainkan di komputer memiliki sifat menghancurkan yang lebih besar dibandingkan kekerasan yang ada di televisi ataupun kekerasan dalam kehidupan nyata sekalipun. Hal ini terjadi terutama pada anak-anak. Mereka akan memiliki kekurangan sensitivitas terhadap sesamanya, memicu munculnya perilaku-perilaku agresif dan sadistis pada diri anak, dan bisa mengakibatkan dorongan kepada anak untuk bertindak kriminal seperti yang dilihatnya (meniru adegan kekerasan).

Solusi :

Dampak negatif tersebut dapat diminimalisasi dengan adanya peran serta dari orang tua. Pertama-tama, orangtualah yang seharusnya mengenalkan computer dan internet pada anak, bukan orang lain. Mengenalkan computer dan internet berarti pula mengenalkan manfaatnya dan tujuan penggunaannya. Selanjutnya orang tua harus dapat mengontrol dan memantau sejauh mana penggunaan komputer dan internet pada anak-anaknya. Seperti memasang software yang dirancang khusus untuk melindungi 'kesehatan' anak. Misalnya saja program nany chip atau parents lock yang dapat memproteksi anak dengan mengunci segala akses yang berbau seks dan kekerasan. Mengatur peletakkan komputer di ruang publik rumah, seperti perpustakaan, ruang keluarga, dan bukan di dalam kamar anak. Memberikan batasan waktu dan jadwal dalam penggunaan komputer.

\section{c) Pornografi}

Anggapan yang mengatakan bahwa internet identik dengan pornografi, memang tidak salah. Dengan kemampuan penyampaian informasi yang dimiliki internet, pornografi pun merajalela. Begitu banyak situs-situs pornografi yang ada di internet, meresahkan banyak pihak terutama kalangan orang tua yang khawatir anak-anaknya akan mengonsumsi hal-hal yang bersifat porno. Di internet terdapat gambar-gambar pornografi yang bisa mengakibatkan dorongan kepada seseorang untuk bertindak kriminal. Ironisnya, ada situs-situs yang memang menjadikan anak-anak sebagai target khalayaknya. Mereka berusaha 
untuk membuat situs yang kemungkinan besar memiliki keterkaitan dengan anak-anak dan sering mereka jelajahi.

Solusi :

Solusi untuk meminimalisasi dampak dari pornografi tersebut tidak jauh berbeda dengan solusi untuk meminimalisasi dampak negatif dari kekejaman dan kesadisan. Dalam hal ini, Pertama-tama, orangtualah yang seharusnya mengenalkan komputer dan internet pada anak, bukan orang lain. Mengenalkan computer dan internet berarti pula mengenalkan manfaatnya dan tujuan penggunaannya. Selanjutnya orang tua harus dapat mengontrol dan memantau sejauh mana penggunaan komputer dan internet pada anak-anaknya.

\section{d) Antisocial Behavior}

Salah satu dampak yang dapat ditimbulkan dari penyalahgunaan komputer adalah antisocial behavior. Dimana pengguna komputer tersebut tidak lagi peduli kepada lingkungan sosialnya dan cenderung mengutamakan komputer. Selain itu, pengguna komputer tersebut tidak peduli lagi apa yang terjadi disekitarnya, satu-satunya yang dapat menarik perhatiannya hanyalah komputer saja. Orang akan menjadi lebih jarang berinteraksi dengan lingkungan di sekitarnya, sehingga kemampuan interpersonal dan emosionalnya tidak berkembang secara optimal. Lama kelamaan, seseorang akan sulit menjalin komunikasi dan membangun relasi dengan orang-orang disekitarnya. Bila hal tersebut tidak segera ditanggulangi akan menumbulkan dampak yang sangat buruk, yang dimana manusia lama kelamaan akan sangat individualis dan tidak akan ada lagi interaksi ataupun sosialisasi.

Solusi :

Antisocial behavior dapat ditanggulangi dengan menciptakan kesadaran dari diri sendiri akan dampak buruk dari antisocial behavior dan mulai memperbanyak kegiatan di luar rumah dengan keuarga atau teman-teman, seperti olahraga bersama, traveling, hang out bersama teman dan sebagainya. Dengan begitu seseorang akan merasakan bahwa sosialisasi dengan sesamanya merupakan suatu kebutuhannya selain kebutuhannya akan komputer.

2) Dampak Teknologi Informasi Bagi Pendidikan

a) Malas belajar dan mengerjakan tugas

Penggunaaan komputer juga menimbulkan dampak negatif dalam dunia pendidikan. Seseorang terutama anak-anak yang terbiasa menggunakan komputer, cenderung menjadi malas karena mereka menjadi lebih tertarik untuk bermain komputer dari pada mengerjakan tugas atau belajar.

Solusi :

Solusi untuk meminimalisasi dampak negatif tersebut yaitu dengan memaksimalkan peran serta orang tua dalam memberikan perhatian, pengertian dan membimbing anak-anak dalam belajar dan bermain. Sehingga bila anakanak dirasa sudah berlebihan dalam menggunakan komputer orang tua bisa segera membatasi dan mencegah terjadinya ketergantungan. 


\section{b) Perubahan Tulisan Tangan}

Dengan kemudahan dan kepraktian yang diberikan oleh komputer, terutama dalam hal menuliskan suatu text, membuat seseorang cenderung memilih untuk mengetik daripada harus menulis secara manual. Akibatnya, lama kelamaan seseorang akan mengalami perubahan tulisan, dari yang dulunya rapih, sampai akhirnya menjadi tulisan yang berantakan dan sulit dibaca, Hal tersebut karena mereka tidak lagi terbiasa untuk menulis secara manual.

Solusi :

Solusi untuk meminimalisasi dampak negatif tersebut yaitu dengan menyeimbangkan antara penggunaan tulisan manual dengan mengetik di komputer. Cobalah untuk tidak hanya mengandalkan komputer untuk membuat suatu text, karena perlu disadari bahwa tidak selamanya kita dapat mengandalkan teknologi. Teknologi hanyalah seperangkat alat yang bisa saja tiba-tiba terjadi kerusakan ataupun error, yang dimana pada saat itu kita tidak dapat lagi mengandalkannya, sehingga kita juga harus dapat menyeimbangkan antara penggunaan secara manual dengan penggunaan teknologi.

3) Dampak Teknologi Informasi Bagi Ekonomi

Persaingan bisnis yang mulai banyak berpengaruh pada masyarakat. Perkembangan teknologi informasi sudah masuk ke penjualan online, akan tetapi Masyarakat masih belum paham bagaimana memanfaatkan internet untuk penjualan.

Solusi:

Penjualan melalui internet banyak cara dilakukan. Masyarakat dilatih menjual hasil produk melalui online. Secara mudahnya dilatih dengan media sosial. Ada beberapa cara teknik berjualan online yang aman. Selain itu dapat memanfaatkan startup yang ada seperti Shopee, Bukalapak, Tokopedia, dan lain sebagainya.

Berikut adalah foto dokumentasi pelaksanaan proses pembinaan kepada Masyarakat di daerah pesisir berlokasi di masjid sebagai tempat penyuluhan:
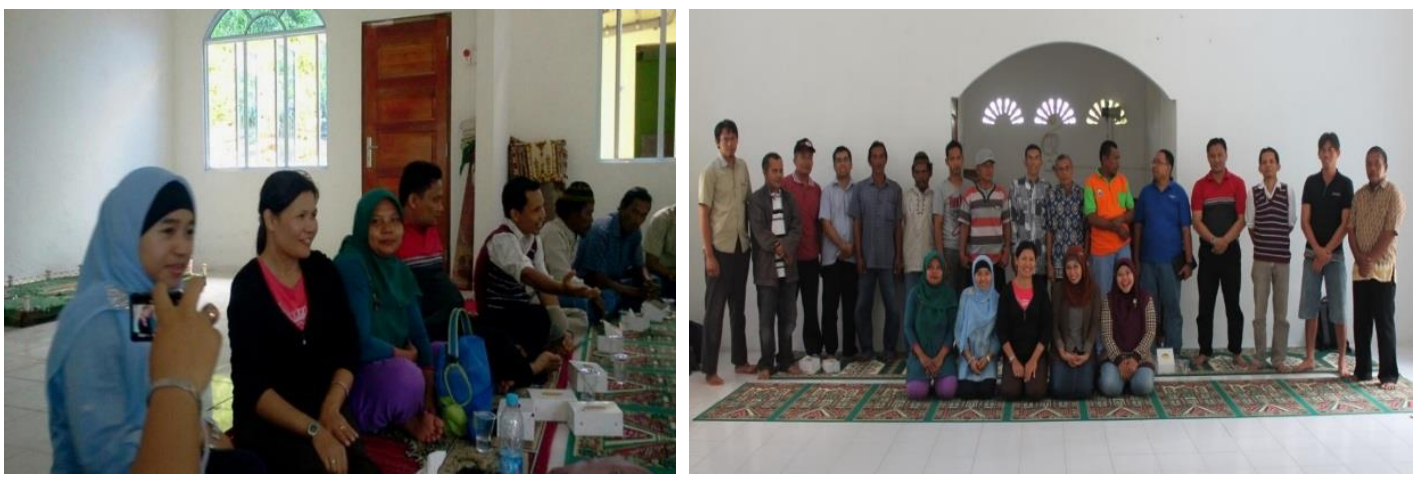

Gambar 1 Foto Kegiatan Pengabdian 


\section{KESIMPULAN}

Adapun kesimpulan yang dapat diambil dari pengabdian masyarakat adalah sebagai berikut:

1) Semua hasil pengembangan IPTEK khususnya dibidang teknologi informasi tersebut telah mampu mengatasi sebagian besar masalah manusia dalam berbagai macam kegiatan pemenuhan kebutuhan hidup. Di zaman yang modern ini semua serba instan, cepat dan tepat. Walaupun demikian, penyalahgunaan IPTEK juga sering dilakukan oleh manusia yang tidak bertanggung jawab dalam kegiatan kejahatan, dan bahkan merusak diri sendiri dan sesama.

2) Dengan kemajuan Teknologi Informasi saat ini memberikan manfaat yang luar biasa pada berbagai sector, bukan saja untuk keperluan bisnis, tetapi sampai pada sektor pendidikan, pemerintahan bahkan politik. Selain dari manfaat yang di berikan kemajuan Teknologi Informasi juga memberikan dampak negative. Pada kesempatan yang lain saya akan menulis mengenai dampak dari kemajuan teknologi saat ini.

3) Teknologi informasi menawarkan peluang perusahaan pemasaran yang sangat baik melalui Internet. Misalnya, perusahaan dapat melakukan riset online untuk mencari tahu apa sebenarnya yang diinginkan pelanggan dan kemudian membuat iklan yang menarik bagi orang-orang. Jika Anda pergi ke sebuah situs web yang iklan liburan pantai, Anda cenderung melihat iklan mengenai tiket pesawat atau penjualan pakaian renang. TI membantu perusahaan untuk menjangkau audiens mereka dengan cepat dan efektif.

4) Meskipun teknologi informasi telah membuat komunikasi yang sangat nyaman dan cepat, telah membawa beberapa masalah privasi juga. Sebagai contoh, pengguna internet yang terkena email hacking dan pencurian identitas.

5) Teknologi Informasi telah menciptakan tingkat konektivitas yang belum pernah terjadi sebelumnya, dengan program dan perangkat telekomunikasi memungkinkan bisnis untuk tetap terhubung secara global untuk gaya hidup mobile. Hasil akhirnya adalah berbagai besar kesempatan kerja bagi pekerja potensial di seluruh dunia. Selain itu, pekerja tidak lagi menghabiskan seluruh hari kerja mereka dalam bilik karena mereka sekarang dapat menggunakan telecommute.

6) Kebanyakan bisnis saat ini tidak hanya menggunakan situs web mereka secara efektif, tetapi mereka juga menggunakan website social networking seperti Twitter dan Facebook. Website ini memungkinkan sesorang atau organisasi untuk berbagi update berita dan informasi lainnya dengan cepat dengan satu sama lain dan dengan konsumen. Ini penyebaran informasi yang menguntungkan sangat penting dalam upaya perusahaan untuk memasarkan jasa dan produk. Teknologi informasi juga memungkinkan pelanggan untuk berkomentar berkaitan dengan barang yang mereka inginkan.

\section{UCAPAN TERIMA KASIH}

Kegiatan pembinaan ini telah dilakukan dengan lancar dengan banyak bantuan dari berbagai pihak. Dengan ini maka ucapan terima kasih kepada LPPM Universitas Putera Batam dan Masyarakat pesisir pulau Belakang Padang. 


\section{DAFTAR PUSTAKA}

Ekawati, Nia. (2020). Penyuluhan Berinternet dan Beribadah Pada Ibu Pengajian Perumahan Bandara Mas. Journal Puan Indonesia.

Arnomo, Sasa Ani. (2018). Penilaian Tingkat Service Toko Online Dan Analisis Perbandingan Perceived Performance. Computer Based Information System Journal, 6(2), 50-59. doi:10.33884/cbis.v6i2.710

Arnomo, Sasa Ani. (2018) Mengukur Ketepatan Kualitas Informasi Sistem Tracer Dan Tracking Jasa Kurir. Computer Based Information System Journal, [S.I.], v. 6, n. 1, p. 56, mar. 2018. ISSN 2621-5292. Available at: <http://ejournal.upbatam.ac.id/index.php/cbis/article/view/641>. Date accessed: 16 dec. 2020. doi: https://doi.org/10.33884/cbis.v6i1.641. 
